\title{
Land-use changes affect the functional structure of stream fish assemblages in a the Brazilian Savanna
}

Correspondence: Rafael Pereira Leitão ecorafa@gmail.com

Submitted February 3, 2021

Accepted August 16, 2021 by Fernando Pelicice Epub October 18, 2021

\author{
${ }^{(0)}$ Ludmilla R. P. Alvarenga ${ }^{1,2},{ }^{(}$Paulo S. Pompeu ${ }^{3},{ }^{\oplus} \mathrm{Cecília} \mathrm{G.} \mathrm{Leal}^{4}$, \\ ${ }^{\circ}$ Robert M. Hughes ${ }^{5,6},{ }^{\circ}$ Daniela C. Fagundes ${ }^{3}$ and ${ }^{\circledR}$ Rafael P. Leitão ${ }^{1}$
}

We investigated the mechanisms involved in the relationship between landuse changes and aquatic biodiversity, using stream fish assemblages of the Brazilian Savanna (i.e., Cerrado) as a study model. We tested the prediction that landscape degradation would decrease environmental heterogeneity and change predominant physical-habitat types, which in turn would decrease the functional diversity and alter the functional identity of fish assemblages. We sampled fish from 40 streams in the Upper Paraná River basin, and assessed catchment and instream conditions. We then conducted an ecomorphological analysis to functionally characterize all species (36) and quantify different facets of the functional structure of assemblages. We detected multiple pathways of the impacts from landscape changes on the fish assemblages. Catchment degradation reduced the stream-bed complexity and the heterogeneity of canopy shading, decreasing assemblage functional specialization and divergence. Landscape changes also reduced the water volume and the amount of large rocks in streams, resulting in decreased abundances of species with large bodies and with morphological traits that favor swimming in the water column. We conclude that land-use intensification caused significant changes in aquatic biodiversity in the Cerrado, reinforcing the need to pay special attention to this global hotspot.

Keywords: Biodiversity hotspot, Functional traits, Human impacts, Landscape degradation, Stream physical habitat.
Online version ISSN 1982-0224

Print version ISSN 1679-6225

Neotrop. Ichthyol.

vol. 19, no. 3, Maringá 2021
1 Laboratório de Ecologia de Peixes, Departamento de Genética, Ecologia e Evolução (DGGE), Instituto de Ciências Biológicas (ICB), Universidade Federal de Minas Gerais (UFMG), Av. Antônio Carlos, 6627, Pampulha, 31270-901 Belo Horizonte, MG, Brazil. (LRPA) ludmillarpa@gmail.com, (RPL) ecorafa@gmail.com (corresponding author).

2 Programa de Pós-Graduação em Ecologia, Conservação e Manejo da Vida Silvestre (ECMVS), Universidade Federal de Minas Gerais (UFMG) Av. Antônio Carlos, 6627, Pampulha, 31270-901 Belo Horizonte, MG, Brazil.

3 Departamento de Ecologia e Conservação, Universidade Federal de Lavras, Campus Universitário, Cx. Postal 3037, 37200-000 Lavras, MG, Brazil. (PSP) pompeups@gmail.com, (DCF) danielafagundes87@gmail.com.

4 Laboratório de Hidrologia Florestal, Escola Superior de Agricultura Luiz de Queiroz, Universidade de São Paulo, 13418-900 Piracicaba, SP, Brazil. c.gontijoleal@gmail.com.

5 Amnis Opes Institute, Corvallis (OR) USA. hughes.bob@amnisopes.com.

6 Department of Fisheries, Wildlife, \& Conservation Sciences, Oregon State University, Corvallis (OR) USA. 
Investigamos os mecanismos envolvidos na relação entre mudanças de uso da terra e biodiversidade aquática, utilizando a ictiofauna de riachos do Cerrado como modelo de estudo. Testamos a predição de que a degradação da paisagem reduz a heterogeneidade ambiental e muda os tipos predominantes de habitat, por sua vez, diminuindo a diversidade e alterando a identidade funcional de comunidades de peixes. Amostramos 40 riachos da bacia do Alto Rio Paraná, e avaliamos as condições da drenagem e do habitat físico local. Em seguida, conduzimos uma análise ecomorfológica para caracterizar funcionalmente todas as espécies (36) e quantificar diferentes facetas da estrutura funcional das comunidades. Detectamos múltiplos caminhos de impacto das alterações da paisagem sobre a ictiofauna. A degradação das bacias de drenagem reduziu complexidade do leito e heterogeneidade no sombreamento pelo dossel, diminuindo especialização e divergência funcional das comunidades. Alterações na paisagem também reduziram volume de água e quantidade de pedras grandes nos riachos, resultando em diminuição na abundância de espécies de maior porte e com atributos morfológicos que favorecem a natação na coluna d'água. Concluímos que a intensificação dos usos da terra causa alterações significativas para a biodiversidade aquática no Cerrado, reforçando a necessidade de especial atenção a este hotspot global.

Palavras-chave: Atributos funcionais, Degradação da paisagem, Habitat físico de riachos, Hotspot de biodiversidade, Impactos humanos.

\section{INTRODUCTION}

A primary goal of contemporary ecology is to understand how biotic communities respond to increasing human-induced pressures across ecosystems. Natural landscapes are being strongly modified by land-use changes, a widespread process on Earth, but especially critical for the tropics (Dirzo et al., 2014). Besides holding huge amounts of biodiversity, the tropics are marked by the conflicting relationship between unsustainable economic growth and the maintenance of ecosystem functioning and services (Costanza et al., 1997; Gardner et al., 2013). The Neotropical Savanna (hereafter Cerrado) is a typical example of such relationships. Although it harbors high levels of species richness and endemism, the Cerrado is one of the most threatened vegetation domains in South America; therefore, it is considered a global biodiversity hotspot for conservation (Myers et al., 2000; Mittermeier et al., 2004). Because of favorable climate, relief and soils (Goedert, 1989), the Cerrado has undergone intense agribusiness pressure in recent decades. As a result, more than $80 \%$ of the original vegetation has been modified for anthropogenic uses (Silva et al., 2013), but only 7\% of the area is legally protected (Soares-Filho et al., 2014). This increasing rate of landscape degradation has led to extensive and intensive impacts on several ecosystems (Santos et al., 2017), including headwater streams and their biota (Carvalho, Tejerina-Garro, 2015; Agra et al., 2021).

Because of the riverscape hierarchical configuration, the replacement of natural vegetation cover by agricultural or urbanized areas in a basin promotes a variety of 
changes in the physical-habitat structure of streams (Wang et al., 2006; Leal et al., 2016; Hughes et al., 2019). For example, catchment deforestation drives soil erosion and sedimentation, and reduces leaf and wood inputs into streams. These processes result in altered substrate types (e.g., from rocky substrate and leaf banks to sand-clay dominated streams), and lower levels of stream-bed complexity and stability, among many other alterations in channel morphology (Leal et al., 2016; Castro et al., 2018; Leitão et al., 2018). Reduced canopy cover means reduced inputs of allochthonous items (e.g., terrestrial insects, fruits and seeds) and increased light penetration, altering energy dynamics for stream food webs (Nakano et al., 1999; Bojsen, Barriga, 2002; Carvalho et al., 2017a). These alterations create two fundamental changes for stream systems: reduced environmental heterogeneity and a shift in predominant habitat types. Consequently, biological assemblages are expected to respond both in terms of diversity and identity/type of species.

The distribution of species over environmental gradients is considered a product of organism-habitat adjustments mediated by their functional traits (e.g., morphology, physiology or behavior). Thus, it is expected that a set of coexisting organisms in a given assemblage reflects, at least in part, the relationship of their traits with the local habitat (Poff, Ward, 1990). Such relationships can be understood both in terms of the variability (i.e., functional diversity) and the predominance of traits (i.e., functional identity) within a biological assemblage (Mouillot et al., 2013). Therefore, in the context of land-use impacts on stream physical habitat, we can expect that reduced environmental heterogeneity would result in lower levels of functional diversity (i.e., Biodiversity-Heterogeneity Hypothesis; MacArthur, MacArthur, 1961). Moreover functional identity may be directly affected by changes in predominant habitat types (i.e., Habitat Templet Hypothesis; Southwood, 1977).

Given the capacity to reveal mechanistic processes driving community assembly (Mouillot et al., 2013), and better performance of functional indexes than pure taxonomic indicators (Teresa, Casatti, 2017), functional approaches have been increasingly applied to understand biodiversity changes over degradation gradients. Particularly for Brazilian headwaters, there has been a remarkable increase in literature focusing on the effects of land use on the functional structure of fish assemblages (Bordignon et al., 2015; Casatti et al., 2015; Roa-Fuentes et al., 2019; Zeni et al., 2020; Teresa et al., 2021). However, some authors have pointed out the context-dependency of this relationship, showing significant differences between study regions resulting from particularities such as geomorphology, landscape degradation level and history (Teresa, Casatti, 2017; Leitão et al., 2018). Additionally, those studies seldom explicitly considered the hierarchical structure of the landscape-habitat-ichthyofauna relationship (but see Dala-Corte et al., 2016 and Leitão et al., 2018). These factors potentially limit our capacity to detect general patterns in the biodiversity response to degradation, and to propose efficient conservation and management strategies for stream fish assemblages. In this context, we conducted a study along a wide gradient of landscape degradation and used path analysis to investigate how land use and cover, mediated by alterations in local physical habitat, affect the functional structure of Cerrado stream fish assemblages. We tested the predictions that landscape degradation would decrease environmental heterogeneity and change predominant physical-habitat types, which in turn would decrease the functional diversity and alter the functional identity of fish assemblages. 


\section{MATERIAL AND METHODS}

Sampling design. We sampled 40 stream sites $(150 \mathrm{~m}$ long) from first to third order (Strahler, 1957) in September 2013 (dry season), all of them draining to Nova Ponte Reservoir in the Araguari River basin, Upper Paraná River, Minas Gerais, Brazil (Figs. 1-2; more details in Fagundes et al., 2015). The sites were selected by using the Generalized Random-Tessellation Stratified (GRTS) method (Stevens, Olsen, 2004; Olsen, Peck, 2008) and therefore were statistically representative of the mosaic of land uses in the region, such as mechanized agriculture (e.g., soybeans, corn, and coffee), pastures, and urban areas, and natural Cerrado vegetation. With this procedure we covered a wide gradient of landscape degradation while maintaining the spatial independence of sampling sites (Macedo et al., 2016).

Landscape degradation. Land use types were assessed using fine resolution images (0.6-5 m spatial resolution; images from Google Earth, 2010) to obtain information about the shape and texture of the elements. We also obtained multispectral images from the TM Landsat sensor, which yields different spectral responses for each type of land use or vegetation cover (Macedo et al., 2014, 2016). Three land uses were then identified and quantified according to their percentages within the entire catchment upstream from each sampled site: pasture, agriculture, or urban. Finally, we calculated the Catchment Disturbance Index (CDI; Ligeiro et al., 2013), which is weighted according to each land-use type as follows:

$$
\mathrm{CDI}=(4 \mathrm{x} \% \text { urban areas })+(2 \times \% \text { agricultural areas })+(1 \times \% \text { pasture areas })
$$

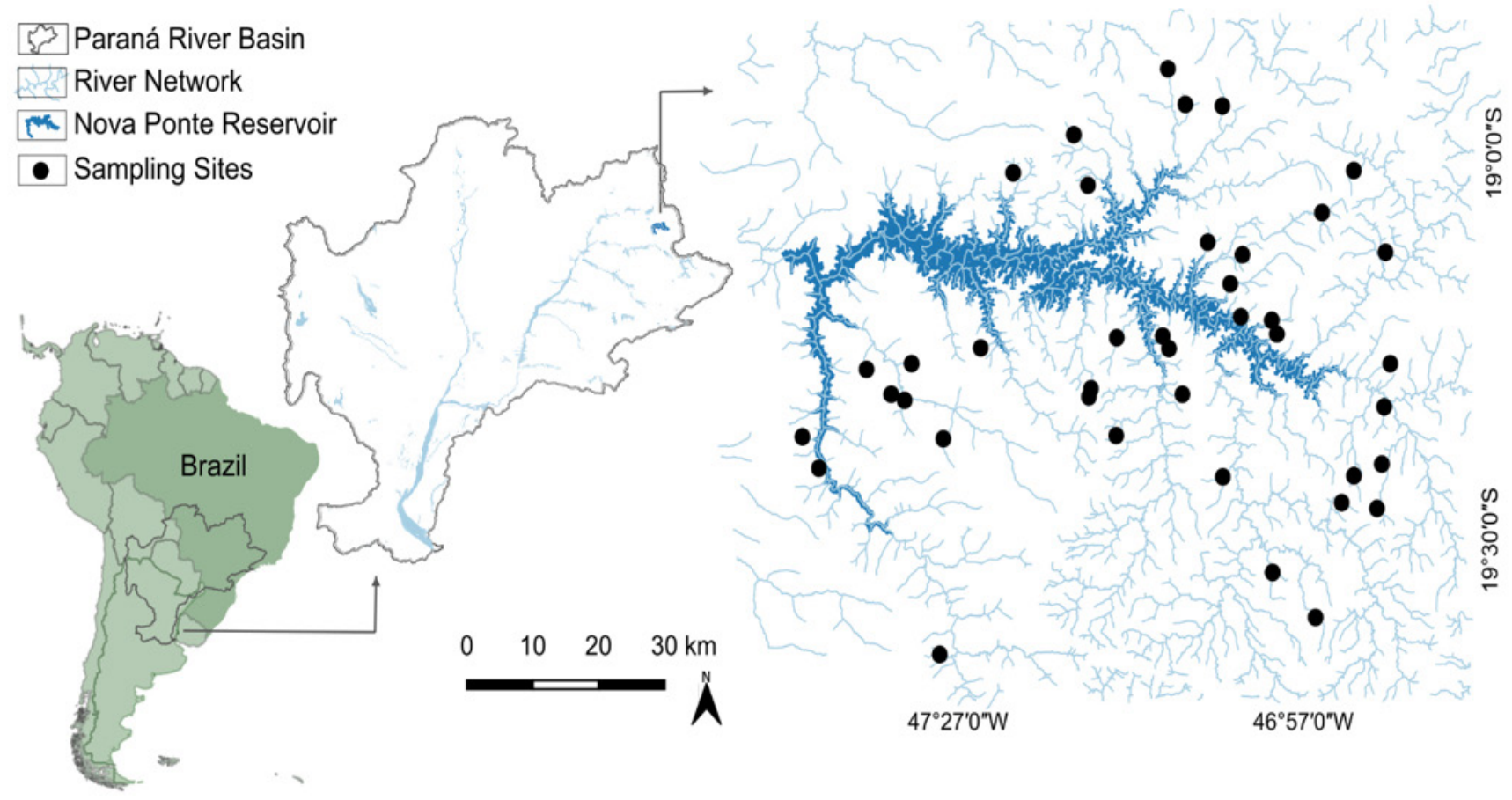

FIGURE 1 I Headwater streams ( $\mathrm{N}=40$; black dots) sampled for fish and local physical habitat. All sites drain to Nova Ponte Reservoir in the Araguari River basin, Upper Paraná River, Minas Gerais, Brazil. 


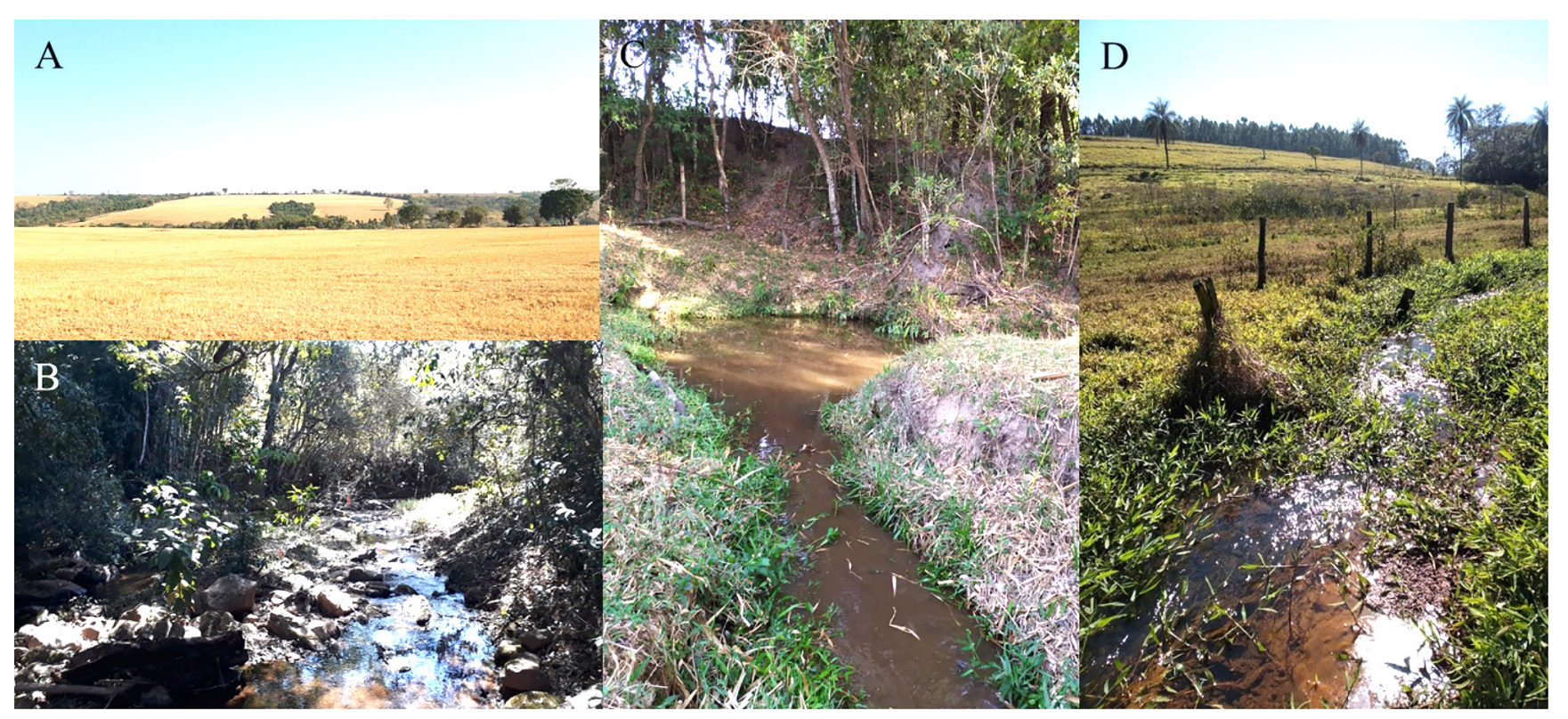

FIGURE 2 I Examples of landscape and local-habitat conditions of the streams sampled across a degradation gradient in the Cerrado: A. Streams with a small strip of riparian forests in landscapes dominated by mechanized agriculture; B. Stream with relatively well-preserved local conditions, including forest on both banks; C. Stream surrounded by intermediate riparian cover; and D. Stream running in pasture areas without any forest.

This index ranges from 0 (absence of the three land-use types) to 400 (catchment fully occupied by urban areas); the higher the CDI value, the greater the level of catchment degradation upstream from each sample site (Ligeiro et al., 2013). The weights established for each type of land use were based on previous studies that considered their severity to the hydromorphological degradation for streams on both temperate (e.g., Böhmer et al., 2004; Feld, 2004; Rawer-Jost et al., 2004) and tropical regions. The latter includes previous assessments conducted for quantifying gradients of catchment anthropogenic disturbance in our study area or in other hydrological units in the Cerrado (e.g., Ligeiro et al., 2013; Carvalho et al., 2017b; Silva et al., 2017; Firmiano et al., 2020; Martins et al., 2020).

Stream physical habitat. Physical habitat measurements were made along the entire $150 \mathrm{~m}$ site, which was divided into ten sections by 11 equidistant cross-sectional transects (see Fig. S1; adapted from Peck et al., 2006). At each of the 11 transects, we obtained: the width of the seasonal bed and of the wetted area of the stream, using a metric tape; the canopy coverage in six points, using a convex densiometer; the angles of both margins, using a clinometer; five equidistant measurements of water depth, using a bathymetric ruler, with respective estimates of the embeddedness level, type of substrates (e.g., coarse gravel, fine gravel, sand, leaf bank, roots), and proportion of the transect with fish shelter (e.g., large wood, macrophytes, undercut banks, overhanging vegetation). In secondary transects placed between a pair of contiguous transects, we also measured the wetted width of the stream channel and five equidistant estimates of substrate types. Along the thalweg profile in each of the ten sections, we obtained 10 equidistant longitudinal measurements of water depth, presence of fine sediments (i.e., 
clay and sand), and type of meso-habitats (e.g., riffles, smooth flow, pool). Along the total area of each section, we also quantified large wood $>1.5 \mathrm{~m}$ long and $>10 \mathrm{~cm}$ in diameter) and channel slope (by clinometer).

These measures yielded more than 200 metrics describing several aspects of the stream physical habitat (e.g., channel morphoplogy, substrate, fish shelter; Kaufmann et al., 1999; Hughes, Peck, 2008; Kaufmann, Faustini, 2012). We selected a subset of 13 variables representative of habitat heterogeneity, complexity, stability and type to run our models based on (i) our expert knowledge and (ii) the literature showing which variables can both be affected by land use and affect stream fish assemblage structure (Kaufmann et al., 1999; Junqueira et al., 2016; Castro et al., 2018; Leal et al., 2018; Leitão et al., 2018). Next, we excluded two variables because of their high correlation with others (Pearson correlation > 0.70) (see Fig. S2), reaching a final subset of 11 variables (Tab. 1). The selection of a reduced subset of variables was important to comply with the analytical constraints of the structural equation modeling (see below) in which the number of variables needs to be balanced against the number of samples.

TABLE 1 I The 11 metrics used to describe the physical habitat of streams from the Araguari River basin. Calculation and ecological meaning based on Kaufmann et al. (1999), Hughes, Peck (2008), and Kaufmann, Faustini (2012).

\begin{tabular}{|c|c|c|c|c|}
\hline Physical-habitat metric & Code & Unit & Calculation & Ecological meaning \\
\hline Mean residual pool area & RP100 & $\mathrm{m}^{2} / 100 \mathrm{~m}$ & $\mathrm{~m}^{2} / 100 \mathrm{~m}$ of channel & $\begin{array}{l}\text { Bed complexity and heterogeneity } \\
\text { provided by residual pools }\end{array}$ \\
\hline Large wood volume & V1W_MSQ & $\mathrm{m} 3 / \mathrm{m}^{2}$ & $\begin{array}{l}\text { Large wood volume }(>1.5 \mathrm{~m} \text { long and }>10 \\
\qquad \mathrm{cm} \text { in diameter)/ stream area }\end{array}$ & $\begin{array}{l}\text { Channel structural complexity and } \\
\text { heterogeneity provided by large wood }\end{array}$ \\
\hline Relative bed stability & LRBS & $\begin{array}{c}\log 10 \\
(\mathrm{~mm} / \mathrm{m})\end{array}$ & Log (critical substrate diameter) & $\begin{array}{l}\text { Stability of the stream bed indicated by } \\
\text { the critical substrate diameter }\end{array}$ \\
\hline Natural fish shelter & XFC_NAT & $\%$ & $X\left(\sum\right.$ natural shelter $)$ & $\begin{array}{l}\text { Habitat heterogeneity and complexity } \\
\text { provided by natural shelter coverage }\end{array}$ \\
\hline Mean canopy cover & XCDENMID & $\%$ & X (\% canopy cover) & Habitat type provided by canopy shading \\
\hline Variation of the canopy cover & VCDENMID & $\%$ & S (\% canopy cover) & $\begin{array}{l}\text { Habitat heterogeneity provided by canopy } \\
\text { shading }\end{array}$ \\
\hline Diversity of meso-habitats & DIV_MH & $\%$ & 1 -Simpson's diversity index & $\begin{array}{l}\text { Habitat heterogeneity provided by } \\
\text { different meso-habitats types }\end{array}$ \\
\hline Wetted area & XWXD & $\mathrm{m}^{2}$ & (X thalweg depth) $*(\mathrm{X}$ channel width) & $\begin{array}{c}\text { Habitat type indicated by stream water } \\
\text { volume }\end{array}$ \\
\hline Large rocky substrates & PCT_BIG & $\%$ & $\begin{array}{l}\% \text { Large rocky substrates }(>16 \mathrm{~mm} \text { in } \\
\text { diameter) }\end{array}$ & $\begin{array}{l}\text { Habitat type provided by large rocky } \\
\text { substrates coverage }\end{array}$ \\
\hline Fine Sediments & PCT_FN & $\%$ & \% Fine sediments (clay, silt and sand) & $\begin{array}{l}\text { Habitat type provided by fine sediments } \\
\text { coverage }\end{array}$ \\
\hline Fast-flowing meso-habitats & PCT_FAST & $\%$ & $\begin{array}{l}\text { Sum of frequencies of all fast-flowing } \\
\text { habitats }\end{array}$ & $\begin{array}{c}\text { Habitat type provided by fast-flowing } \\
\text { meso-habitats }\end{array}$ \\
\hline
\end{tabular}


Fish sampling. Fish were collected during daylight hours, using semicircular sieves ( $80 \mathrm{~cm}$ in diameter, $1 \mathrm{~mm}$ mesh) and seines ( $4 \mathrm{~m}$ long, $2 \mathrm{~m}$ high and $5 \mathrm{~mm}$ mesh). The effort was standardized over a period of two hours (12 min per section) of sampling by three people along the 150-m site. In the field, all specimens were anesthetized in a lethal dose of Eugenol's solution, and then fixed in 10\% formalin. In the laboratory, fish were preserved in 70\% alcohol and identified to species using keys and consultation with specialists. Voucher specimens of all species are deposited in the Fish Collection at the Federal University of Lavras (CIUFLA), Minas Gerais, Brazil (voucher numbers in Tab. S3).

Functional structure of the fish assemblages. To assess the functional structure of the fish assemblages, an ecomorphological analysis was first performed. For this, body mass and morphometric measurements (see Fig. S4) were taken in adult specimens (one to seven per species) and then combined into 12 quantitative ecomorphological traits. Together, these traits represent complementary functional characteristics, such as habitat use, foraging and locomotion (Tab. 2; see Leitão et al., 2018 for further details). The mean values of each trait by species were first scaled (mean $=0$ and standard deviation $=1$ ) and used to build a matrix of Euclidean distance between each pair of species. Based on this matrix, we performed a Principal Component Analysis (PCA) to reduce dimensionality and build the functional space with the species pool (i.e., all species sampled in the study). We kept the first three axes of the PCA ( $64.8 \%$ of accumulated variance), which were necessary to accommodate the high quality of the functional space and minimize the loss of information (Villéger et al., 2008; Maire et al., 2015). However, this procedure still led to the exclusion of 10 sites that lacked enough species to calculate the functional indexes in a three-dimensional functional space.

Based on the position of fish species in the three-dimensional functional space, and their relative abundances, five complementary indices were calculated to represent the functional diversity of each assemblage: Functional Richness (FRic), Functional Evenness (FEve), Functional Divergence (FDiv), Functional Originality (FOri), and Functional Specialization (FSpe). FRic is the volume of the functional space filled by the species of an assemblage, representing the combination of the functional traits. FEve measures the regularity of the distance among species and the uniformity of their abundances in the functional space. FDiv indicates how species abundance is distributed in relation to the assemblage centroid in the functional space, being low when more abundant species are closer to the centroid, and high when the most abundant species are at the edges of the functional space (Villéger et al., 2008). FOri quantifies the degree of uniqueness, being expressed by the distance of each species to its closest neighbor in the functional space. FSpe quantifies the degree of specialization of a species, expressed by its distance to the centroid of the functional space, considering all the species pool (Mouillot et al., 2013). FOri and FSpe are initially calculated for each species and then scaled for the assemblage by calculating the mean value of the species in an assemblage. To estimate functional identity, we used the community-weighted mean of a trait (CWM; Lavorel et al., 2008). Because we used an ordination technique (PCA) to construct the functional space (i.e., we did not build the functional space directly with the original ecomorphological traits as the functional dimensions), CWM is expressed as the abundance-weighted average 
TABLE 2 I The 12 ecomorphological traits used to functionally characterize fish species of streams from the Araguari River basin and their ecological significance. Codes for the initial morphological measurements used to calculate traits according to Fig. S4.

\begin{tabular}{|c|c|c|c|c|}
\hline Ecomorphological trait & Code & Calculation & Ecological meaning & References \\
\hline Oral-gape shape & Osh & $\frac{\mathrm{Md}}{\mathrm{Mw}}$ & Capture mode of the food item & Karpouzi, Stergiou (2003) \\
\hline Oral-gape position & Ops & $\frac{\mathrm{Mo}}{\mathrm{Hd}}$ & $\begin{array}{l}\text { Feeding strategy in the water } \\
\text { column }\end{array}$ & $\begin{array}{l}\text { adapted from } \\
\text { Sibbing, Nagelkerke (2001) }\end{array}$ \\
\hline Eye size & Edst & $\frac{\mathrm{Ed}}{\mathrm{Hd}}$ & Prey detection & $\begin{array}{c}\text { adapted from } \\
\text { Boyle, Horn (2006) }\end{array}$ \\
\hline Eye position & Eps & $\frac{\mathrm{Eh}}{\mathrm{Hd}}$ & $\begin{array}{l}\text { Vertical position in the water } \\
\text { column }\end{array}$ & Gatz (1979) \\
\hline Body transversal shape & Bsh & $\frac{\mathrm{Bd}}{\mathrm{Bw}}$ & $\begin{array}{l}\text { Vertical position in the water } \\
\text { column and hydrodynamics }\end{array}$ & Sibbing, Nagelkerke (2001) \\
\hline Body transversal surface & Bsf & $\frac{\ln [(\pi / 4 \times \text { Bw } \times \text { Bd })+1]}{\ln (\text { Mass }+1)}$ & $\begin{array}{l}\text { Distribution of mass throughout } \\
\text { the body for hydrodynamics }\end{array}$ & Villéger et al. (2010) \\
\hline Pectoral-fin position & PFps & $\frac{\mathrm{PFi}}{\mathrm{PFb}}$ & Manuverability & Dumay et al. (2004) \\
\hline Aspect ratio of the pactoral fin & PFar & $\frac{\mathrm{PFl}^{2}}{\mathrm{PFs}}$ & Pectoral fin propulsion & $\begin{array}{l}\text { adapted from } \\
\text { Fulton et al. (2001) }\end{array}$ \\
\hline Caudal-peduncle throttling & $\mathrm{CPt}$ & $\frac{\mathrm{CFd}}{\mathrm{CPd}}$ & $\begin{array}{l}\text { Swimming efficiency by reducing } \\
\text { water resistance }\end{array}$ & Webb (1984) \\
\hline Aspect ratio of the caudal fin & CFar & $\frac{\mathrm{CFd}^{2}}{\mathrm{CFs}}$ & $\begin{array}{l}\text { Propulsion and steering by caudal } \\
\text { fin }\end{array}$ & Webb (1984) \\
\hline Fins surface ratio & Frt & $\frac{2 \times \mathrm{PFs}}{\mathrm{CFs}}$ & Main type of propulsion & Villéger et al. (2010) \\
\hline Mass & $\log M$ & $\log$ (Mass +1) & $\begin{array}{l}\text { Metabolism, endurance and } \\
\text { swimming ability }\end{array}$ & Villéger et al. (2010) \\
\hline
\end{tabular}

value for each PC axis (i.e., CWM1, CWM2 and CWM3), and the loading of each trait is considered in the subsequent interpretations regarding the CWM values. All functional indices were calculated using the multidimFD package in $\mathrm{R}$ ( $\mathrm{R}$ Development Core Team, 2019).

Data analysis. Structural equation modeling (SEM) was performed to investigate the possible ways by which landscape degradation, mediated by changes in stream physical habitat, affect fish assemblage functional structure. This method is capable of simultaneously evaluating several pathways to represent the functioning of the system from relationships between variables at different spatial extents and representing a mechanistic approach to ecological studies (Shipley, 2000). Based on the literature focusing on the relationships between land use, physical habitat and stream biodiversity 
(e.g., De Paula et al., 2011; Casatti et al., 2012; Teresa, Casatti, 2012; Junqueira et al., 2016; Castro et al., 2018; Leitão et al., 2018), we tested two hypothetical models, both with the CDI as a predictor of environmental degradation at the landscape spatial extent (Fig. 3).

The first model presents a structure in which the biological response is the assemblage functional diversity expressed by the five above-mentioned indices (i.e., FRic, FEve, FDiv, FOri and FSpe) and the site predictive variables are metrics that represent stream habitat heterogeneity and environmental stability (Fig. 3A; see ecological meaning of each physical-habitat metric in Tab. 1). Because of the processes associated with soil erosion, sedimentation, and removal of forest vegetation, we expected that catchment degradation would negatively affect streambed complexity (RP100) and stability (LRBS), meso-habitat diversity (DIV_MH), wood volume (V1W_MSQ), the variation in channel shading by riparian vegetation (VCDENMID), and the amount of natural shelters for fish (XFC_NAT) (Fig. 3A).

The second model presents a structure in which the biological response is the functional identity of the fish assemblages (i.e., CWM1, CWM2 and CWM3), and the predictive variables are the site habitat types (Fig. 3B; Tab. 1). In this sense, we expected changes in the functional identity in response to landscape degradation mediated by decreased wood volume in the channel (V1W_MSQ) and mean canopy shading (XCDEMID). We also expected that functional identity changes would result from catchment erosion and sedimentation processes that could reduce wetted area (XWXD), the amount of large substrates (PCT_BIGR) and the frequency of fast-flowing meso-habitats (PCT_ FAST), while increasing the amount of fine sediments (PCT_FN) (Fig. 3B).

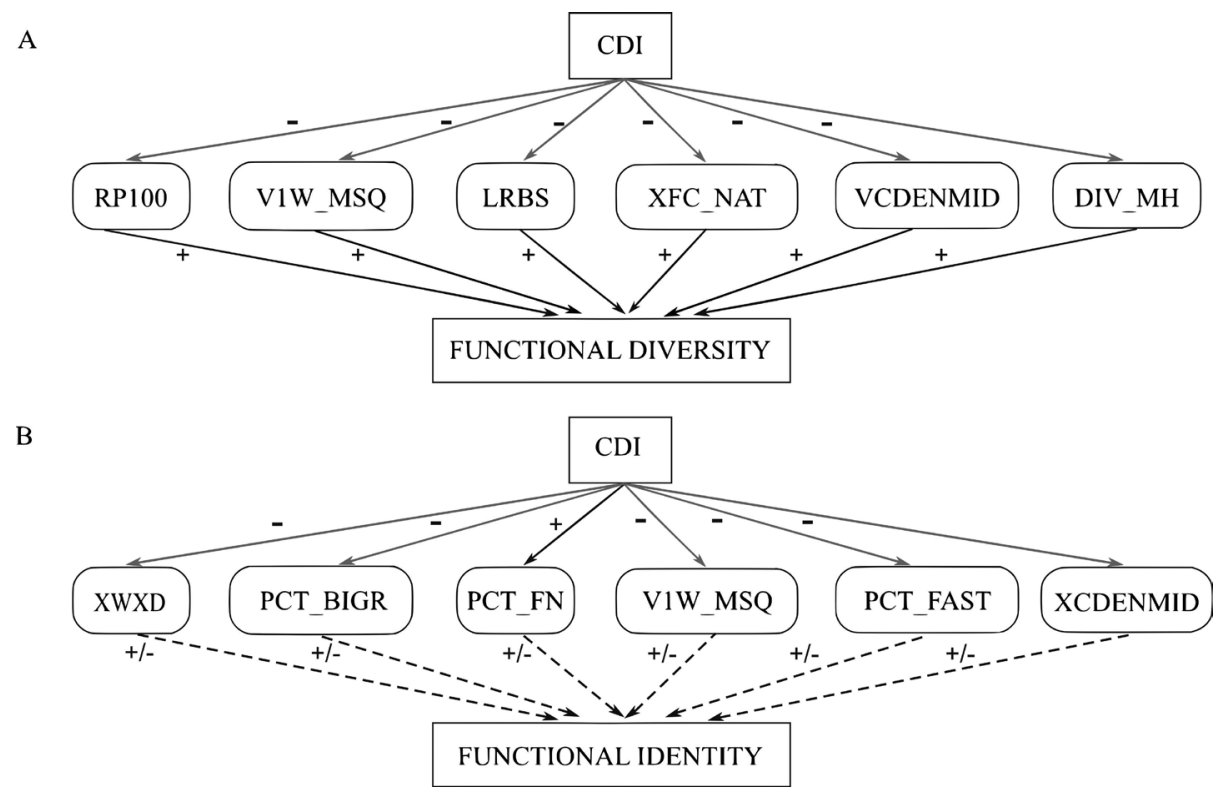

FIGURE 3 I Predictions tested using structural equation modeling, indicating the expected pathways (arrows) for the effects of catchment degradation (CDI) on stream physical habitat and, consequently, on the functional structure of the fish assemblages. Land use is expected to influence the functional diversity mediated by alterations in habitat heterogeneity and stability (A), and to influence functional identity, mediated by changes in habitat type (B). Arrows indicate expected effects between predictive and response variables, which can be positive (black continuous line), negative (gray continuous line) or non-directional (dashed lines). For physical-habitat codes, calculation and ecological meaning, see Tab. 1. 
We used Bollen-Stine bootstrap (1000 draws) to evaluate the overall fit of the models, which is an adaptation of the chi-square statistic considered robust to non-normal data distributions (Bollen, Stine, 1992) and measures the correspondence between the model and the observed data structure. Standardized path coefficients that were not statistically significant were retained in the model (i.e., we did not re-specify the structural model a posteriori) but were not included in figures to simplify visualization of the significant paths. Modeling was conducted through use of the lavaan package in $\mathrm{R}$ ( $\mathrm{R}$ Development Core Team, 2019).

\section{RESULTS}

Fish assemblage composition. A total of 5,460 individuals from 36 species, 12 families and six orders were collected (see Tab. S3), with mean richness of 8.3 species $(4-14)$ and mean abundance of 187 individuals $(10-696)$ per site. The family with the most species (11) and individuals (3.130) was Characidae, followed by Trichomycteridae $(\mathrm{S}=$ $4 ; \mathrm{N}=877)$ and Loricariidae $(\mathrm{S}=4 ; \mathrm{N}=726)$.

Effects of landscape degradation on functional diversity. Catchment degradation was negatively associated with residual pools (RP100), stream-bed stability (LRBS), and canopy cover variability (VCDENMID). Given that RP100 was positively associated with FDiv (+0.40), FEve (+0.32) and FSpe $(+0.27)$, CDI had a negative indirect effect on these three functional diversity metrics through this pathway (Fig. 4A; see the product of the two significant direct effects linking them, from CDI to RP100 and from RP100 to functional indexes, in Tab. 3). VCDENMID was positively associated with FSpe $(+0.38)$, FRic $(+0.36)$ and FOri $(+0.51)$, meaning a negative indirect effect of CDI on these functional metrics (Fig. 4A; Tab. 3). On the other hand, VCDENMID was negatively associated with FEve (-0.28) and LRBS was negatively associated with FRic (-0.32) and FOri (-0.36), meaning a positive indirect effect of CDI on functional diversity through these pathways (Fig. 4A; Tab. 3). Summing up the multiple pathways of land use impacts on functional diversity, there was a stronger total negative effect on FSpe (sum of the products of all paths from CDI to FSpe $=-0.23$ ) and FDiv (-0.16), a small negative effect on FEve (-0.03) and FOri (-0.03), and no effect on FRic (Tab. 3). Although FRic was positively influenced by the diversity of meso-habitats, the latter was not associated with the CDI. The number of species strongly and positively affected FRic, but it was not affected by any physical habitat predictor. Large wood volume and natural shelters for fish were positively associated with CDI, but they had no effect on any biodiversity metric (Fig. 4A).

Effect of landscape degradation on functional identity. Landscape degradation at the catchment extent (CDI) also affected aspects of fish assemblage functional identity, mediated by a reduction of the wetted area (XWXD) and the amount of large substrates (PCT_BIGR) in the stream channel (Fig. 4B). Both physical-habitat metrics were positively associated with CWM2, leading to an indirect and total negative effect of $\mathrm{CDI}$ on this functional index (sum of the products of all paths from CDI to CWM2 = -0.35 ; Tab. 3). This means that the greater the CDI score, the less the water volume 
and large substrate, and the lower the abundance and occurrence of species positioned at the positive extreme of PC2 (see Fig. 5). Besides having heavier bodies (body mass $(\log M)$ with high positive loading for PC2; Fig. 5; Tab. S5), these species have deep caudal fins (positive loadings of CFar for PC2; Fig. 5; Tab. S5), pectoral fins positioned lower on the body (negative loadings of PFps for PC2; Fig. 5; Tab. S5), and lower values for body transversal surface (negative loadings of Bsf for PC2; Fig. 5; Tab. S5). The mean canopy shading and the amount of fine sediment were positively associated with, respectively, CWM1 and CWM2, but those physical-habitat metrics were not influenced by catchment degradation (Fig. 4B). CWM3 was not affected by any habitat metric.
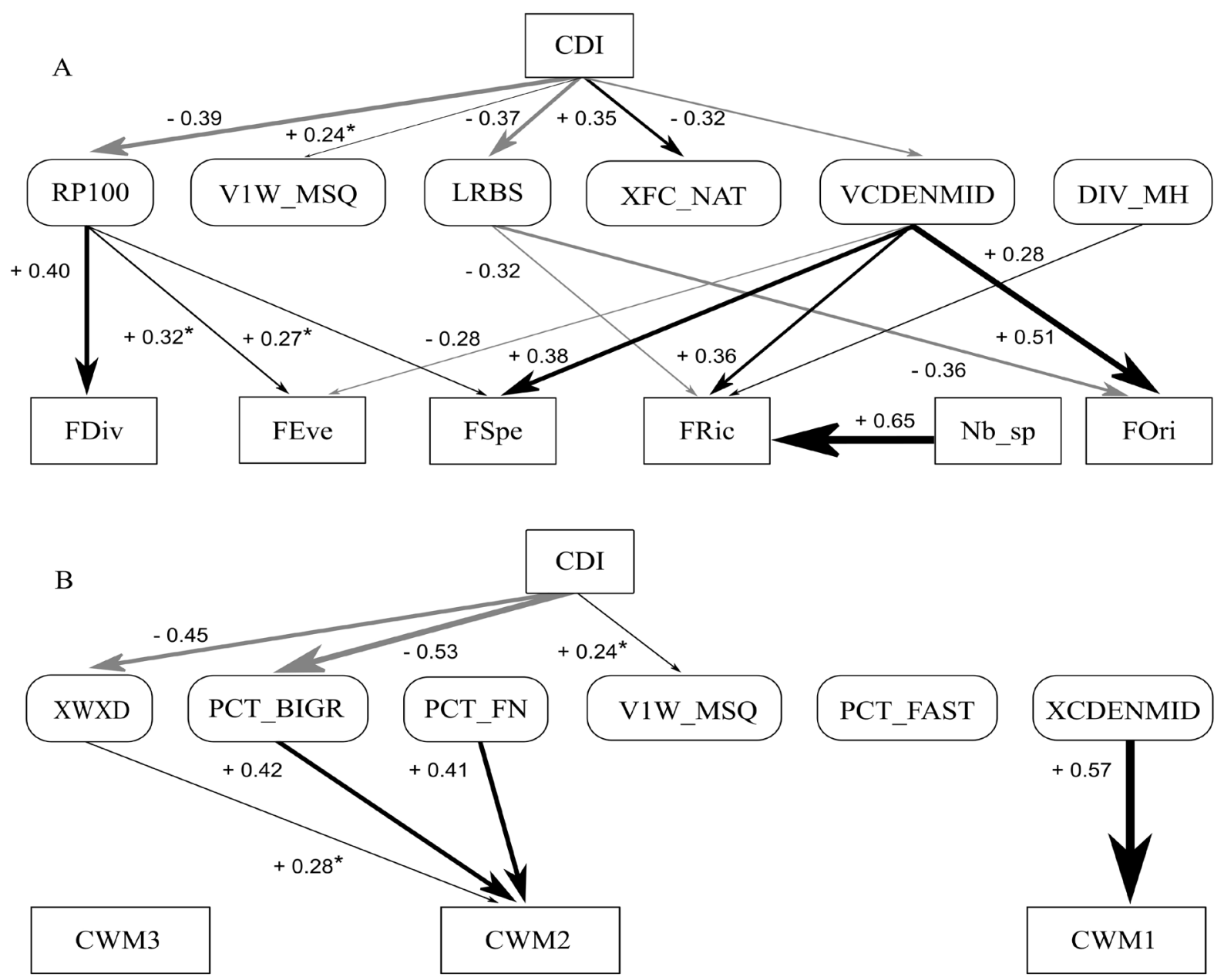

FIGURE 4 I Structural equation model diagrams showing the effects of landscape degradation (CDI) on the functional structure of stream fish assemblages from the Araguari River basin. CDI influenced functional diversity mediated by alterations in habitat heterogeneity and stability (A. Model fit: X2 = 32.8, df = 25, p = 0.51). CDI also influenced functional identity, mediated by changes in habitat type (B. Model fit: $\mathrm{X} 2=44.9, \mathrm{df}=18, \mathrm{p}=0.13)$. Arrows indicate positive (black) and negative (gray) significant direct effects $\left(\mathrm{p}<0.05 ;{ }^{*} \mathrm{p}<0.10\right)$, with thickness proportional to their power (standardized path coefficients along arrows). Biodiversity metrics - FRic: Functional Richness; FDiv: Functional Divergence; FEve: Functional Evennes; FSpe: Functional Specialization; FOri: Functional Originality; CWM1-3: Functional Identity. For physical-habitat codes, calculation and ecological meaning, see Tab. 1. 
TABLE 3 I Total and indirect effects of catchment degradation (CDI), mediated by instream physical-habitat metrics, on the functional structure of the stream fish assemblages from the Araguari River basin. FDiv: functional divergence, FOri: functional originality, FSpe: functional specialization, FRic: functional richness, FEve: functional evenness, Nb_sp: number of species, CWM1-3: functional identity. The indirect effect of CDI on each functional index, mediated by instream physical habitat, is calculated by multiplying the standardized path coefficients (taking into account the signal, positive or negative) of the two significant direct effects linking them (arrows in Fig. 4): i) from CDI to a physical-habitat metric; ii) from that physical-habitat metric to the functional index. For instance, the indirect effect of CDI on FDiv via RP100 is -0.16 ((-0.39) * $(+0.40))$. The total effect of CDI on a given functional index is the sum of all significant indirect effects linking them. For instance, the total effect of CDI on FSpe is -0.23 (via RP100 (-0.11) + via VCDENMID (-0.12)). See graphical representation and the direct-effect paths in Fig. 4.

\begin{tabular}{|c|c|c|c|c|c|c|c|c|c|}
\hline Variable & Code & FDiv & FOri & FSpe & FRic & FEve & CWM1 & CWM2 & CWM3 \\
\hline Catchment disturbance index & CDI & $-0,16$ & $-0,03$ & $-0,23$ & 0,00 & $-0,03$ & - & $-0,35$ & - \\
\hline Residual pools & RP100 & $-0,16$ & - & -0.11 & - & -0.12 & - & - & - \\
\hline Volume of wood & V1W_MSQ & - & - & - & - & - & - & - & - \\
\hline Relative bed stability & LRBS & - & 0.13 & - & 0.12 & - & - & - & - \\
\hline Natural fish shelter & XFC_NAT & - & - & - & - & - & - & - & - \\
\hline Variation of the canopy cover & VCDENMID & - & -0.16 & -0.12 & -0.12 & 0.09 & - & - & - \\
\hline Mean canopy cover & XCDENMID & & & & & & & & \\
\hline Diversity of meso-habitats & DIV_MH & - & - & - & - & - & - & - & - \\
\hline Wetted area & XWXD & - & - & - & - & - & - & -0.13 & - \\
\hline Large rocky substrates & PCT_BIGR & - & - & - & - & - & - & -0.22 & - \\
\hline Fine sediments & PCT_FN & - & - & - & - & - & - & - & - \\
\hline Fast-flowing meso-habitats & PCT_FAST & - & - & - & - & - & - & - & - \\
\hline Number of species & Nb_sp & - & - & - & - & - & - & - & - \\
\hline
\end{tabular}
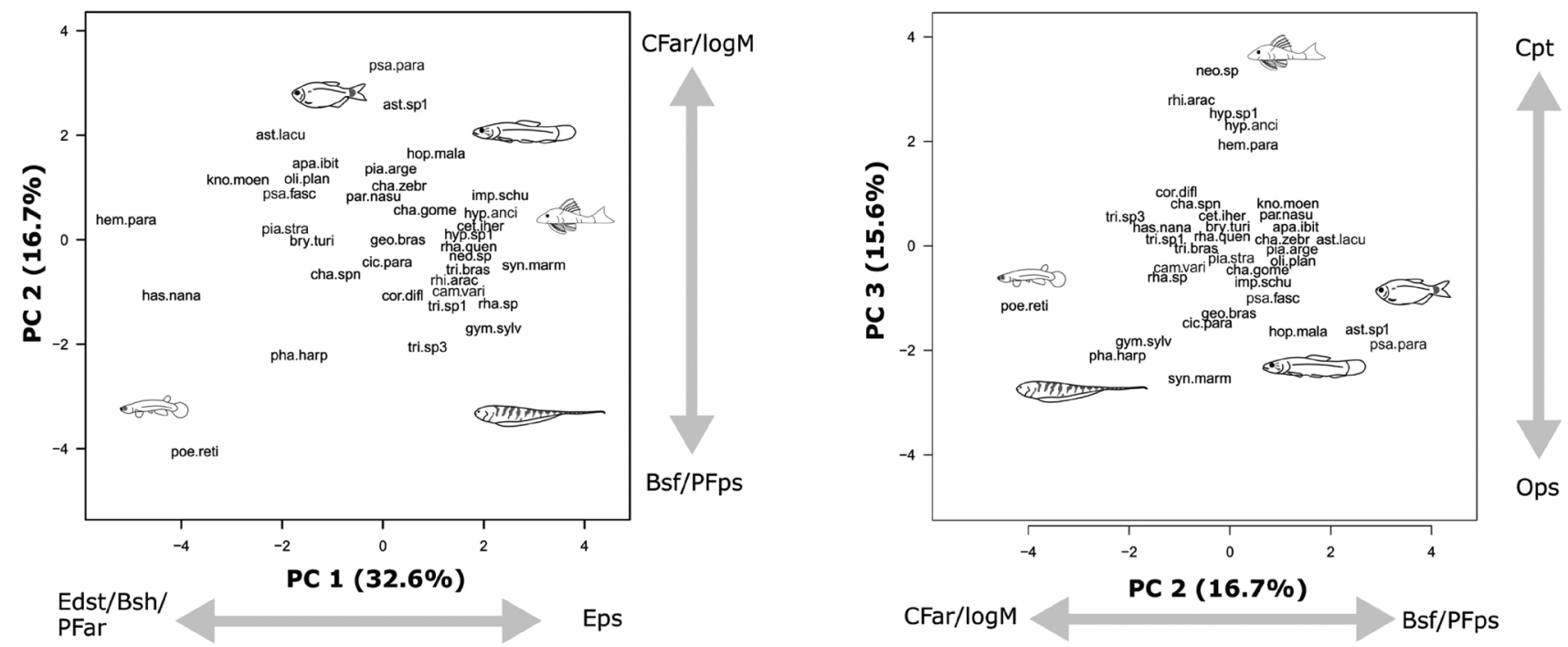

FIGURE 5 I Ecomorphological space showing the position of each fish species (36) from the Araguari River basin. Each plot represents two axes of a principal component analysis (PCA), where species are plotted according to their respective trait values. Codes at the ends of the arrows are the most important ecomorphological traits for each PCA axis. For trait and species codes, see Tab. 2 and Tab. S3, respectively). 


\section{DISCUSSION}

In this study we aimed to understand mechanisms that explain the relationship between land uses (i.e., agriculture, pasture and urbanization) and aquatic biodiversity, using stream fish assemblages of the Cerrado as a model. This relationship was investigated by focusing on how the variability and types of fish functional traits responded to instream habitat changes associated with landscape degradation. We used two independent and complementary frameworks, the first hypothesizing that decreased environmental heterogeneity would decrease functional diversity, and the second hypothesizing that changes in stream habitat types would alter the functional identity of assemblages. We observed multiple pathways and various intensities of impacts of landscape degradation on fish assemblages, in great part corroborating our expectations. Catchment degradation (CDI) reduced the heterogeneity and stability of stream habitats, leading to a decrease in four (FDiv, FSpe, FEve and FOri) out of the five functional diversity indexes tested. Changes in catchment condition also resulted in changes in the habitat types, altering the predominant functional traits (i.e., functional identity) within assemblages. These results were allied to the fact that all the physical habitat metrics that were negatively influenced by catchment degradation (i.e., RP100, LRBS, VCDENMID, WXWD, PCT_BIGR) were those that mediated the paths of land-use effects on the assemblage functional structure. Therefore, we can conclude that land-use intensification resulted in significant changes and losses in aquatic biodiversity in the Cerrado, reinforcing the need to pay special attention to this global hotspot.

The negative impacts of landscape degradation on the functional diversity of fish assemblages were mediated by a decrease in residual pool volume. This variable (RP100) is expressed as the relative residual thalweg depth (Kaufmann et al., 1999, 2009), which contributes to micro-habitat diversity resulting from the variability in depth along the stream (Petty, Grossman, 1996), and is inversely related to silting processes (Kaufmann et al., 1999). Therefore, reduced levels of RP100 are likely explained by soil erosion from watersheds (Allan et al., 1997; Allan, 2004), a typical result of agrobusiness activities in the Cerrado (Casatti et al., 2006; Castro et al., 2018). Given that RP100 is a direct indicator of stream-bed complexity (Kaufmann, Faustini, 2012), its reduction should affect diversity components of the fish assemblages. Indeed, this degradation pathway reduced assemblage functional divergence (FDiv), specialization (FSpe) and evenness (FEve).

Another important pathway of impact resulting from landscape degradation is the reduced variability in channel shading by canopy vegetation (VCDENMID), also an indicator of reduced environmental heterogeneity of these systems (e.g., deforested areas can be completely homogeneous in terms of shading over the channel). The distribution of organisms within streams frequently follows patch dynamics because of the heterogeneous distribution of habitat and food resources (Petty, Grossman, 1996; Leitão et al., 2015). For example, several fishes forage in leaf banks or close to tree roots and branches, which are more frequent where marginal vegetation is denser (Da Silva Gonçalves et al., 2018). On the other hand, periphyton feeders tend to occur in areas with greater light incidence and greater algae production (Bojsen, Barriga, 2002), a condition found even in pristine systems (e.g., wider stream stretch not fully covered by the canopy or running in natural riparian-forest clearings). Therefore, scaling up these 
specificities to the assemblage level, we can expect a positive relationship between the variation in shading over the stream channel and functional diversity. This expectation was corroborated in this study, given that three different functional diversity metrics (FRic, FSpe and FOri) were positively associated with VCDENMID.

Overall, the most negatively affected metrics of functional diversity were FSpe and FDiv. The first was doubly reduced, by both the decrease in RP100 and VCDENMID in degraded catchments, and the latter was the most negatively affected metric considering a single pathway. In biological and ecological terms, reducing FSpe and FDiv means reducing the level of specialization and the number of individuals with highly specialized ecomorphological traits (i.e., far from the center of gravity of the functional space; Villéger et al., 2008). Assuming the fine-tuned relationship between morphology and function (Winemiller, 1991), the loss of such traits from an assemblage can represent the disruption of important ecological processes within the system (Leitão et al., 2016), such as the use and partitioning of habitat and food, with consequent changes in patterns of species packing (Winemiller, 1991), and several other ecological interactions among coexisting species (Mouillot et al., 2013).

Not only diversity, but fish functional identity was also significantly affected by land use changes. Landscape degradation reduced the wetted area (XWXD) and the percent of large substrates (PCT_BIGR) in the stream channel, which led to a decrease in abundance and occurrence of species with larger bodies and with morphological traits that favor fast swimming and endurance in the water column (e.g., deep caudal fins, pectoral fins positioned lower on the body, and lower values for body transversal surface). Given that XWXD takes into account the channel width and the thalweg depth, it is an indication of the amount of water in the system (Kaufmann et al., 1999; Hughes, Peck, 2008). Large rocks also contribute to the formation of deep mesohabitats, such as pools and backwater, by retaing water and shaping the stream channel (Rincón, 1999). Therefore, reducing XWXD and PCT_BIGR represents the loss of critical habitats for large and mid-water column feeders (e.g., Astyanax and Psalidodon species in the studied systems). On the other hand, shallow streams would favor smaller fishes with high body transversal surface, represented here by the poeciliids, especially the widespread invasive species, Poecilia reticulata Peters, 1859 (see its position in the ecomorphological space, Fig. 5).

These results partially corroborates Carvalho et al. (2017b), who developed fish-based multimetric indices (MMI) to assess the condition of Cerrado streams. Carvalho et al. (2017b) studied our sampled sites in the Araguari River basin and other hydrological units from the Upper Paraná River, and found that higher abundances of characiforms and $P$. reticulata were indicative of, respectivelly, least- and most-disturbed streams. Besides occupying deeper areas, several stream-dwelling characins are allochthonous feeders, and dependent on least disturbed habitats and adjacent forest (Ferreira, Casatti, 2006). On the other hand, P. reticulata is extremely tolerant to poor water quality (Terra et al., 2013; Carvalho et al., 2019). Therefore, although using completely different aproaches (ecomorphological versus biological/physiological traits), it was possible to identify convergent patters in the relationship between landscape degradation and stream fish assemblages in the Cerrado.

Although the overall results of this study corroborated our initial predictions about the negative relationship between land use changes, stream physical habitat and the 
functional structure of the fish assemblages, we also found unexpected relationships. For instance, although negatively associated with CDI, the relative bed stability of streams (LRBS) reduced FRic and FOri, and VCDENMID reduced FEve. Therefore, summing up all pathways of impacts, the total effect of catchment degradation on each of these three functional diversity metrics was almost null (i.e., negative and positive effects compensated each other by different pathways). Another unexpected result was the positive relationship of CDI with the amount of natural shelter and wood volume within streams. A possible interpretation for this result is the influence of deforestation history in the Cerrado, particularly of the riparian forests. Streams surrounded by more vegetation are likely to have greater wood volume in their channels (Leal et al., 2016). However, in the initial periods following riparian deforestation, high amounts of wood inputs can be expected (De Paula et al., 2011). Also, riparian deforestation leads to increased abundance of aquatic macrophytes, which offer considerable shelter for fishes. Further investigations evaluating landscape degradation history and deforestation timing (e.g., Brejão et al., 2018) may clarify these unexpected relationships.

Tropical landscapes are facing intense alterations, especially resulting from the expansion of agricultural lands over natural ecosystems (Malhi et al., 2014), severely threatening global hotspots of biodiversity such as the Cerrado (Mittermeier et al., 2004). Particularly regarding Brazilian freshwaters, environmental legislation seems insufficient to preserve the ichthyofauna (Dala-Corte et al., 2020; Leal et al., 2020). Additionally, conservation strategies still largely neglect aquatic biota, although it was recently shown that focusing on this component of biodiversity would represent impressive gains with minimal extra financial costs (Leal et al., 2020). Therefore, continued efforts and innovative tools are urgently needed to better understand, control and remediate the human-induced impacts on the functioning of freshwater ecosystems (Leitão et al., 2018). We are in accordance with the growing consensus that one of these tools is to seek for and quantify biological responses taking into account the multiple facets of biodiversity (Mouillot et al., 2013; Teresa, Casatti, 2017). For instance, we did not detect changes in taxonomic diversity (i.e., the number of fish species), despite the fact that different aspects of the functional structure of fish assemblages were clearly responsive to alterations in stream habitat type and heterogeneity. Therefore, we believe that, by demonstrating pathways by which land-use changes affect the functional diversity and identity of stream fish assemblages, this study bring important insights to improve conservation and management strategies to one of the most ecologically and economically important regions of the Neotropics.

\section{ACKNOWLEDGMENTS}

We thank Dr. Diego Castro and Dr. Gilberto N. Salvador for their critical suggestions on earlier versions of the manuscript, MSc. Carlos A. Rodrigues-Filho for helping with the illustrations, Dr. Diego Macedo for the land use data, Lorena Miranda, Gabriela Moreira Ronzani, Dennys Drager and MSc. Gabriel Aguila for helping with the ecomorphological measurements. We are also grateful for the Instituto Brasileiro do Meio Ambiente e dos Recursos Naturais Renováveis (IBAMA) for the collecting license (10327-1). This study was financially supported by Agência Nacional de Energia Elétrica 
and Companhia Energética de Minas Gerais (P\&D ANEEL/CEMIG-GT487 and P\&D ANEEL/CEMIG-GT599 - PROECOS Project). LRPA received CAPES scholarship (88887.199567/2018-00), PSP received CNPq productivity grant (303548/2017-7), CGL received FAPESP funding (2017/25383-0), RMH received a Fulbright Brazil scholarship, and RPL received CNPq funding (436007/2018-5).

\section{REFERENCES}

- Agra J, Ligeiro R, Heino J, Macedo DR, Castro DMP, Linares MS et al. Anthropogenic disturbances alter the relationships between environmental heterogeneity and biodiversity of stream insects. Ecol Indic. 2021; 121:107079. https://doi.org/10.1016/j. ecolind.2020.107079

- Allan D, Erickson D, Fay J. The influence of catchment land use on stream integrity across multiple spatial scales. Freshw Biol. 1997; 37(1):149-61. https://doi. org/10.1046/j.1365-2427.1997.d01-546.x

- Allan JD. Landscapes and riverscapes: the influence of land use on stream ecosystems. Annu Rev Ecol Evol Syst. 2004; 35:257-84. https://doi.org/10.1146/annurev. ecolsys.35.120202.110122

- Böhmer J, Rawer-Jost C, Zenker A, Meier C, Feld CK, Biss R, Hering D. Assessing streams in Germany with benthic invertebrates: development of a multimetric invertebrate based assessment system. Limnologica. 2004; 34(4):41632. https://doi.org/10.1016/S00759511(04)80010-0

- Bojsen BH, Barriga R. Effects of deforestation on fish community structure in Ecuadorian Amazon streams. Freshw Biol. 2002; 47(11):2246-60. https://doi. org/10.1046/j.1365-2427.2002.00956.x

- Bollen KA, Stine RA. Bootstrapping goodness-of-fit measures in structural equation models. Sociol Methods Res. 1992; 21(2):205-29. https://doi.org/10.1177/00491 24192021002004

- Bordignon CR, Casatti L, PérezMayorga MA, Teresa FB, Brejão GL. Fish complementarity is associated to forests in Amazonian streams. Neotrop Ichthyol. 2015; 13(3):579-90. https://doi. org/10.1590/1982-0224-20140157

- Boyle K, Horn M. Comparison of feeding guild structure and ecomorphology of intertidal fish assemblages from central California and central Chile. Mar Ecol Prog Ser. 2006; 319:65-84. https://doi. org/10.3354/meps319065
- Brejão GL, Hoeinghaus DJ, PérezMayorga MA, Ferraz SFB, Casatti L. Threshold responses of Amazonian stream fishes to timing and extent of deforestation. Conserv Biol. 2018; 32(4):860-71. https://doi.org/10.1111/ cobi.13061

- Carvalho DR, Castro DMP, Callisto M, Moreira MZ, Pompeu PS. The trophic structure of fish communities from streams in the Brazilian Cerrado under different land uses: an approach using stable isotopes. Hydrobiologia. 2017a; 795(1):199-217. https://doi.org/10.1007/ s10750-017-3130-6

- Carvalho DR, Flecker AS, Alves CBM, Sparks JP, Pompeu PS. Trophic responses to aquatic pollution of native and exotic livebearer fishes. Sci Total Environ. 2019; 681:503-15. https://doi.org/10.1016/j. scitotenv.2019.05.092

- Carvalho DR, Leal CG, Junqueira NT, Castro MA, Fagundes DC, Alves CBM et al. A fish-based multimetric index for Brazilian savanna streams. Ecol Indic. 2017b; 77:386-96. https://doi.org/10.1016/j. ecolind.2017.02.032

- Carvalho RA, Tejerina-Garro FL. Environmental and spatial processes: what controls the functional structure of fish assemblages in tropical rivers and headwater streams? Ecol Freshw Fish. 2015; 24(2):317-28. https://doi.org/10.1111/ eff.12152

- Casatti L, Langeani F, Silva AM, Castro RMC. Stream fish, water and habitat quality in a pasture dominated basin, southeastern Brazil. Braz J Biol. 2006; 66(2b):681-96. https://doi.org/10.1590/ S1519-69842006000400012

- Casatti L, Teresa FB, Gonçalves-Souza T, Bessa E, Manzotti AR, Gonçalves CS et al. From forests to cattail: how does the riparian zone influence stream fish? Neotrop Ichthyol. 2012; 10(1):205-14. https://doi.org/10.1590/S167962252012000100020 
- Casatti L, Teresa FB, Zeni JO, Ribeiro MD, Brejão GL, Ceneviva-Bastos M. More of the same: high functional redundancy in stream fish assemblages from tropical agroecosystems. Environ Manage. 2015; 55(6):1300-14. https://doi.org/10.1007/ s00267-015-0461-9

- Castro DMP, Dolédec S, Callisto M. Land cover disturbance homogenizes aquatic insect functional structure in neotropical savanna streams. Ecol Indic. 2018; 84:573-82. https://doi.org/10.1016/j. ecolind.2017.09.030

- Costanza R, d'Arge R, de Groot R, Farber S, Grasso M, Hannon B, Limburg K et $\boldsymbol{a l}$. The value of the world's ecosystem services and natural capital. Nature. 1997; 387(6630):253-60. https://doi. org/10.1038/387253a0

- Dala-Corte RB, Giam X, Olden JD, Becker FG, Guimarães TF, Melo AS. Revealing the pathways by which agricultural land-use affects stream fish communities in South Brazilian grasslands. Freshw Biol. 2016; 61(11):1921-34. https://doi.org/10.1111/ fwb.12825

- Dala-Corte RB, Melo AS, Siqueira T, Bini LM, Martins RT, Cunico AM et al. Thresholds of freshwater biodiversity in response to riparian vegetation loss in the Neotropical region. J Appl Ecol. 2020; 57(7):1391-402. https://doi. org/10.1111/1365-2664.13657

- Dirzo R, Young HS, Galetti M, Ceballos G, Isaac NJB, Collen B. Defaunation in the Anthropocene. Science. 2014; 345(6195):401-06. https://doi.org/10.1126/ science. 1251817

- Dumay 0, Tari PS, Tomasini JA, Mouillot D. Functional groups of lagoon fish species in Languedoc Roussillon, southern France. J Fish Biol. 2004; 64(4):970-83. https://doi. org/10.1111/j.1095-8649.2004.00365.x

- Fagundes DC, Leal CG, Carvalho DR, Junqueira NT, Langeani F, Pompeu PS. The stream fish fauna from three regions of the Upper Paraná River basin. Biota Neotrop. 2015; 15(2):e20140187. https://doi. org/10.1590/1676-06032015018714

- Feld CK. Identification and measure of hydromorphological degradation in Central European lowland streams. Hydrobiologia. 2004; 516:69-90. https://doi. org/10.1023/B:HYDR.0000025259.01054.f2
- Ferreira CP, Casatti L. Integridade biótica de um córrego na bacia do alto rio Paraná avaliada por meio da comunidade de peixes. Biota Neotrop. 2006; 6(3):1-25. Available from: https:// www.biotaneotropica.org.br/v6n3/pt/ abstract?article+bn00306032006

- Firmiano KR, Cañedo-Argüelles M, Gutiêrrez-Cánovas C, Macedo DR, Linares MS, Bonada N, Callisto M. Land use and loal environment affect macroinvertebrate metacommunity organization in Neotropical stream networks. J Biogeogr. 2020; 48:479-91. https://doi.org/10.1111/jbi.14020

- Fulton CJ, Bellwood DR, Wainwright PC. The relationship between swimming ability and habitat use in wrasses (Labridae). Mar Biol. 2001; 139:25-33. https://doi.org/10.1007/s002270100565

- Gardner TA, Ferreira J, Barlow J, Lees AC, Parry L, Vieira ICG et al. A social and ecological assessment of tropical land uses at multiple scales: the sustainable Amazon network. Philos Trans R Soc B Biol Sci. 2013; 368:20120166. https://doi.org/10.1098/ rstb.2012.0166

- Gatz AJ. Community organization in fishes as indicated by morphological features. Ecology. 1979; 60(4):711-18. https://doi. org/10.2307/1936608

- Goedert WJ. Região dos Cerrados: potencial agrícola e política para seu desenvolvimento. Pesqui Agropecuária Bras. 1989; 24(1):1-17. Available from: https://seer.sct.embrapa.br/index.php/pab/ article/viewFile/13716/7776

- Hughes RM, Infante DM, Wang L, Chen K, Terra BF. Advances in understanding landscape influences on freshwater habitats and biological assemblages. Bethesda: American Fisheries Society; 2019. (Symposium; 90) https://doi. org/10.47886/9781934874561

- Hughes RM, Peck DV. Acquiring data for large aquatic resource surveys: the art of compromise among science, logistics, and reality. J North Am Benthol Soc. 2008; 27(4):837-59. https://doi.org/10.1899/08028.1

- Junqueira NT, Macedo DR, Souza RCR, Hughes RM, Callisto M, Pompeu PS. Influence of environmental variables on stream fish fauna at multiple spatial scales. Neotrop Ichthyol. 2016; 14(3):e150116. https://doi.org/10.1590/1982-0224-20150116 
- Karpouzi VS, Stergiou KI. The relationships between mouth size and shape and body length for 18 species of marine fishes and their trophic implications. J Fish Biol. 2003; 62(6):135365. https://doi.org/10.1046/j.10958649.2003.00118.x

- Kaufmann PR, Faustini JM. Simple measures of channel habitat complexity predict transient hydraulic storage in streams. Hydrobiologia. 2012; 685:69-95. https://doi.org/10.1007/s10750-011-0841-y

- Kaufmann PR, Larsen DP, Faustini JM. Bed stability and sedimentation associated with human disturbances in Pacific Northwest streams. J Am Water Resour Assoc. 2009; 45(2):434-59. https://doi. org/10.1111/j.1752-1688.2009.00301.x

- Kaufmann PR, Levine P, Robison EG, Seeliger C, Peck DV. Quantifying physical habitat in wadeable streams. EPA/620/R-99/003. Washington, DC: US Environmental Protection Agency; 1999. Available from: https://nepis. epa.gov/Exe/ZyPDF.cgi/300042RU. PDF?Dockey=300042RU.PDF

- Lavorel S, Grigulis K, McIntyre S, Williams NSG, Garden D, Dorrough J et al. Assessing functional diversity in the field - Methodology matters! Funct Ecol. 2008; 22(1):134-47. https://doi.org/10.1111/ j.1365-2435.2007.01339.x

- Leal CC, Lennox GD, Ferraz SFB, Ferreira J, Gardner TA, Thomson JR et al. Integrated terrestrial-freshwater planning doubles conservation of tropical aquatic species. Science. 2020; 370:117-21. https://www.science.org/doi/10.1126/ science.aba7580

- Leal CG, Barlow J, Gardner TA, Hughes RM, Leitão RP, Mac Nally R et al. Is environmental legislation conserving tropical stream faunas? A large-scale assessment of local, riparian and catchment-scale influences on Amazonian fish. J Appl Ecol. 2018; 55(3):1312-26. https://doi.org/10.1111/1365-2664.13028

- Leal CG, Pompeu PS, Gardner TA, Leitão RP, Hughes RM, Kaufmann PR et al. Multi-scale assessment of human-induced changes to Amazonian instream habitats. Landsc Ecol. 2016; 31(8):1725-45. https:// doi.org/10.1007/s10980-016-0358-x
- Leitão RP, Sánchez-Botero JI, Kasper D, Trivério-Cardoso V, Araújo CM, Zuanon J et al. Microhabitat segregation and fine ecomorphological dissimilarity between two closely phylogenetically related grazer fishes in an Atlantic Forest stream, Brazil. Environ Biol Fishes. 2015; 98(9):2009-19. https://doi.org/10.1007/s10641-015-0423-3

- Leitão RP, Zuanon J, Mouillot D, Leal CG, Hughes RM, Kaufmann PR et al. Disentangling the pathways of land use impacts on the functional structure of fish assemblages in Amazon streams. Ecography. 2018; 41:219-32. https://doi. org/10.1111/ecog.02845

- Leitão RP, Zuanon J, Villéger S, Williams SE, Baraloto C, Fortune C et al. Rare species contribute disproportionately to the functional structure of species assemblages. Proc R Soc B Lond Biol Sci. 2016; 283(1828):20160084. https://doi. org/10.1098/rspb.2016.0084

- Ligeiro R, Hughes RM, Kaufmann PR, Macedo DR, Firmiano KR, Ferreira WR et al. Defining quantitative stream disturbance gradients and the additive role of habitat variation to explain macroinvertebrate taxa richness. Ecol Indic. 2013; 25:45-57. https://doi. org/10.1016/j.ecolind.2012.09.004

- MacArthur RH, MacArthur JW. On bird species diversity. Ecology. 1961; 42(3):59498. https://doi.org/10.2307/1932254

- Macedo DR, Hughes RM, Ferreira WR, Firmiano KR, Silva DRO, Ligeiro R et al. Development of a benthic macroinvertebrate multimetric index (MMI) for Neotropical Savanna headwater streams. Ecol Indic. 2016; 64:132-41. https://doi.org/10.1016/j. ecolind.2015.12.019

- Macedo DR, Hughes RM, Ligeiro R, Ferreira WR, Castro MA, Junqueira NT et al. The relative influence of catchment and site variables on fish and macroinvertebrate richness in cerrado biome streams. Landsc Ecol. 2014; 29:1001-16. https://doi.org/10.1007/s10980014-0036-9

- Maire E, Grenouillet G, Brosse S, Villéger S. How many dimensions are needed to accurately assess functional diversity? A pragmatic approach for assessing the quality of functional spaces. Glob Ecol Biogeogr. 2015; 24(6):728-40. https://doi. org/10.1111/geb.12299 
- Malhi Y, Gardner TA, Goldsmith GR, Silman MR, Zelazowski P. Tropical forests in the Anthropocene. Annu Rev Environ Resour. 2014; 39:125-59. https://doi.org/10.1146/annurevenviron-030713-155141

- Martins I, Macedo DR, Hughes RM, Callisto M. Are multiple multimetric indices effective for assessing ecological condition in tropical basins? Ecol Indic. 2020; 110:105953. https://doi.org/10.1016/j. ecolind.2019.105953

- Mittermeier RA, Gil PR, Hoffmann M, Pilgrim J, Brooks T, Mittermeier CG, Lamoreux J, Fonseca GAB. Hotspots revisited. Cemex; 2004.

- Mouillot D, Graham NAJ, Villéger S, Mason NWH, Bellwood DR. A functional approach reveals community responses to disturbances. Trends Ecol Evol. 2013, 28(3):167-77. https://doi.org/10.1016/j. tree.2012.10.004

- Myers N, Mittermeier RA, Mittermeier CG, Fonseca GAB, Kent J. Biodiversity hotspots for conservation priorities. Nature. 2000; 403(6772):853-58. https://doi. org/10.1038/35002501

- Nakano S, Miyasaka H, Kuhara N. Terrestrial-aquatic linkages: riparian arthropod inputs alter trophic cascades in a stream food web. Ecology. 1999; 80(7):2435-41. https://doi.org/10.1890/00129658(1999)080[2435:TALRAI]2.0.CO;2

- Olsen AR, Peck D V. Survey design and extent estimates for the Wadeable Streams Assessment. J North Am Benthol Soc. 2008; 27(4):822-36. https://doi.org/10.1899/08050.1

- De Paula FR, Ferraz SFDB, Gerhard P, Vettorazzi CA, Ferreira A. Large woody debris input and its influence on channel structure in agricultural lands of Southeast Brazil. Environ Manage. 2011; 48:750-63. https://doi.org/10.1007/s00267-011-9730-4

- Peck DV, Herlihy BH, Hill RM, Hughes PR, Kaufmann DJ, Klemm JM et al. Environmental monitoring and assessment program - surface waters Western pilot study: field operations manual for wadeable streams. EPA/620/R. Washington, DC: US Environmental Protection Agency; 2006.

- Petty JT, Grossman GD. Restricted movement by mottled sculpin (Pisces: Cottidae) in a southern Appalachian stream. Freshw Biol. 1996; 49(5):63145. https://doi.org/10.1111/j.13652427.2004.01216.x
- Poff NL, Ward JV. Physical habitat template of lotic systems: recovery in the context of historical pattern of spatiotemporal heterogeneity. Environ Manage. 1990; 14:629-45. https://doi. org/10.1007/BF02394714

- R Development Core Team. R: A language and environment for statistical computing. [Computer software manual - Internet]. Vienna: R Foundation for Statistical Computing; 2019.

- Rawer-Jost C, Zenker A, Böhmer J. Reference conditions of German stream types analysed and revised with macroinvertebrates fauna. Limnologica. 2004; 34(4):390-97. https://doi.org/10.1016/ S0075-9511(04)80008-2

- Rincón PA. Uso do micro-hábitat em peixes de riachos: métodos e perspectivas. In: Caramaschi EP, Mazzoni R, PeresNeto PR, editores. Ecologia de peixes de riachos. Rio de Janeiro: Programa de Pós-Graduação em Ecologia, Instituto de Biologia, Universidade Federal do Rio de Janeiro; 1999. p.23-90. (Oecologia Brasiliensis; v. 6).

- Roa-Fuentes CA, Heino J, Cianciaruso MV, Ferraz S, Zeni JO, Casatti L. Taxonomic, functional, and phylogenetic $\beta$-diversity patterns of stream fish assemblages in tropical agroecosystems. Freshw Biol. 2019; 64(3):447-60. https://doi. org/10.1111/fwb.13233

- Santos JC, Lisboa GS, França LCJ, Stepka TF, Silva JBL, Miranda DLC et al. Relação entre variáveis meteorológicas e o uso e ocupação do solo no Sudoeste do Piauí, Brasil. Nativa. 2017; 5(6):414-20. https:// doi.org/10.5935/2318-7670.v05n06a06

- Shipley B. A new inferential test for path models based on directed acyclic graphs. Struct Equ Modeling. 2000; 7(2):206-18. https://doi.org/10.1207/ S15328007SEM0702_4

- Sibbing FA, Nagelkerke LAJ. Resource partitioning by Lake Tana barbs predicted from fish morphometrics and prey characteristics. Rev Fish Biol Fish. 2001; 10:393-437. https://doi. org/10.1023/A:1012270422092

- Silva CR, Souza KB, Furtado WF. Evaluation of the progress of intensive agriculture in the Cerrado Piauiense Brazil. IERI Procedia. 2013; 5:51-58. https:// doi.org/10.1016/j.ieri.2013.11.069 
- Silva DRO, Herlihy AT, Hughes RM, Callisto M. An improved macroinvertebrate multimetric index for the assessment of wadeable streams in the neotropical savanna. Eco Ind. 2017; 81:514-25. https://doi.org/10.1016/j. ecolind.2017.06.017

- Da Silva Gonçalves C, Souza Braga FM, Casatti L. Trophic structure of coastal freshwater stream fishes from an Atlantic rainforest: evidence of the importance of protected and forest-covered areas to fish diet. Environ Biol Fishes. 2018; 101:933-48. https://doi.org/10.1007/s10641-018-0749-8

- Soares-Filho B, Rajão R, Macedo M, Carneiro A, Costa W, Coe M et al. Cracking Brazil's forest code. Science. 2014; 344(6182):363-64. https://doi.org/10.1126/ science. 1246663

- Southwood TRE. Habitat, the templet for ecological strategies? J Anim Ecol. 1977; 46(2):336-65. https://doi.org/10.2307/3817

- Stevens DL, Olsen AR. Spatially balanced sampling of natural resources. J Am Stat Assoc. 2004; 99(465):262-78. https://doi. org/10.1198/016214504000000250

- Strahler AN. Quantitative analysis of watershed geomorphology. Eos (Washington DC). 1957; 38(6):913-20. https://doi.org/10.1029/TR038i006p00913

- Teresa FB, Casatti L. Trait-based metrics as bioindicators: responses of stream fish assemblages to a gradient of environmental degradation. Ecol Indic. 2017; 75:249-58. https://doi.org/10.1016/j. ecolind.2016.12.041

- Teresa FB, Casatti L. Influence of forest cover and mesohabitat types on functional and taxonomic diversity of fish communities in Neotropical lowland streams. Ecol Freshw Fish. 2012; 21(3):433-42. https://doi.org/10.1111/j.16000633.2012.00562.x
- Teresa FB, Rodrigues-Filho CAS, Leitão RP. Diversidade funcional de peixes de riacho. Oecologia Australis. 2021; 25(2):415-32. https://doi.org/10.4257/ oeco.2021.2502.12

- Terra BDF, Hughes RM, Francelino MR, Araújo FG. Assessment of biotic condition of Atlantic Rain Forest streams: a fishbased multimetric approach. Ecol Indic. 2013; 34:136-48. https://doi.org/10.1016/j. ecolind.2013.05.001

- Villéger S, Mason NWH, Mouillot D. New multidimensional functional diversity indices for a multifaceted framework in functional ecology. Ecology. 2008; 89(8):2290-301. https://doi.org/10.1890/071206.1

- Villéger S, Miranda JR, Hernández DF, Mouillot D. Contrasting changes in taxonomie $v s$. functional diversity of tropical fish communities after habitat degradation. Ecol Appl. 2010; 20(6):151222. https://doi.org/10.1890/09-1310.1

- Wang L, Seelbach PW, Hughes RM. Introduction to landscape influences on stream habitats and biological assemblages. Am Fish Soc Symp. 2006; 2006(48):1-23.

- Webb PW. Form and function in fish swimming. Sci Am. 1984; 251(1):72-82. https://doi.org/10.1038/ scientificamerican0784-72

- Winemiller KO. Ecomorphological diversification in lowland freshwater fish assemblages from five biotic regions. Ecol Monogr. 1991; 61(4):343-65. https://doi. org $/ 10.2307 / 2937046$

- Zeni JO, Hoeinghaus DJ, Roa-Fuentes CA, Casatti L. Stochastic species loss and dispersal limitation drive patterns of spatial and temporal beta diversity of fish assemblages in tropical agroecosystem streams. Hydrobiologia. 2020; 847:3829-43. https://doi.org/10.1007/s10750-020-04356-1

\section{AUTHORS' CONTRIBUTION}

Ludmilla Rodrigues Pimenta Alvarenga: Conceptualization, Data curation, Formal analysis,

Investigation, Methodology, Validation, Visualization, Writing-original draft, Writing-review and editing.

Paulo Santos Pompeu: Conceptualization, Data curation, Formal analysis, Funding acquisition,

Investigation, Methodology, Project administration, Validation, Visualization, Writing-original draft,

Writing-review and editing.

Cecília Gontijo Leal: Data curation, Formal analysis, Investigation, Methodology, Supervision,

Visualization, Writing-review and editing.

Robert M. Hughes: Conceptualization, Investigation, Methodology, Validation, Visualization, Writingreview and editing. 


\section{Neotropical Ichthyology}

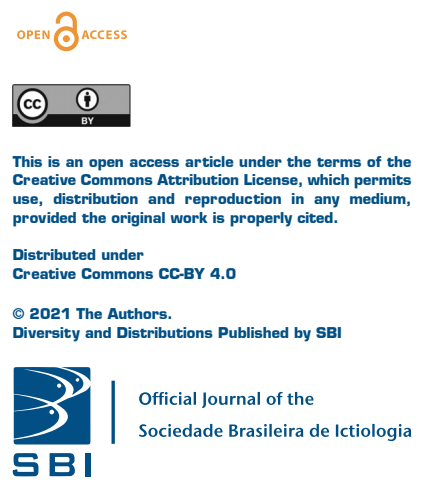

Daniela Cristina Fagundes: Data curation, Formal analysis, Investigation, Methodology, Validation, Visualization, Writing-review and editing.

Rafael Pereira Leitão: Conceptualization, Data curation, Formal analysis, Funding acquisition, Investigation, Methodology, Project administration, Supervision, Validation, Visualization, Writingoriginal draft, Writing-review and editing.

\section{ETHICAL STATEMENT}

Sampling of specimens was conducted using a license number (10327-1) granted by the Sistema de Autorização em Informação em Biodiversidade (SISBIO), and according to the recommendations of the National Council of Animal Experimentation Control (CONCEA).

\section{COMPETING INTERESTS}

The authors declare no competing interests.

\section{HOW TO CITE THIS ARTICLE}

- Alvarenga LRP, Pompeu PS, Leal CG, Hughes RM, Fagundes DC, Leitão RP. Land-use changes affect the functional structure of stream fish assemblages in the Brazilian Savanna. Neotrop Ichthyol. 2021; 19(3):e210035. https://doi.org/10.1590/1982-0224-2021-0035 